\title{
Nauczyciel wobec nieładu światowego - czyli o potrzebie (redefinicji) świadomości zadań nauczyciela w sytuacji kontrolowanych i niekontrolowanych zmian oraz możliwościach wykorzystania sztuki w procesie ich oswajania
}

Streszczenie: Prezentowany tekst jest próbą zwrócenia uwagi na potrzeby oswojenia dokonujących się zmian w przestrzeni globalnej. Zagrożenia i konsekwencje współcześnie dokonujących się przemian w wieloaspektowym zakresie implikują potrzebę podejmowania zintegrowanych działań edukacyjnych. W tekście uwagę skupiam na działaniach szkoły/nauczyciela w sytuacji nieładu światowego. Istotną kwestią pozostaje świadomość nauczycieli oraz ich aktywność wychowawczo-edukacyjna zorientowana na kreowanie świadomości młodych ludzi wobec permanentnych zmian oraz zjawiska wielokulturowości. Jak wskazują minione epoki, istotnym instrumentem regulującym pozytywne współistnienie, relacje społeczne, wspólne funkcjonowanie pozostaje kultura i sztuka, będąca nie tylko odzwierciedleniem rzeczywistości, ale ważnym społecznym komunikatem, materiałem edukacyjnym, a nade wszystko spoiwem społeczności, szczególnie wielokulturowych. Uwzględniając wartość kultury/sztuki, nie tylko jej artyzm, estetykę, ale jej utylitaryzm, celowym zamysłem pozostaje włączenie jej do działań edukacyjnych.

Słowa kluczowe: zmiany, nieład, zagrożenia, kultura, sztuka, edukacja, nauczyciel, oswajanie, potrzeba, świadomość.

\section{Na wstępie}

Przemiany, dynamika, globalizacja, chaos, labilność, migracja, ryzyko, nieład, zagrożenia, odpowiedzialność, strach... - to tylko niektóre terminy charakteryzujące współczesną codzienność. Terminy wydają się znane, zrozumiałe i oswojone, ale co z ich treścią, czy także jest zrozumiała i oswojona? Już tylko pobieżny ogląd rzeczywistości - jakości życia, możliwości realizacji funkcji, relacji społecznych, poczucia szczęścia - ujawnia, że obecność, tudzież 
posługiwanie się wspomnianymi terminami wcale nie oznacza ich zrozumienia i akceptacji. Przeciwnie - coraz powszechniej obserwujemy wobec nich opór, niechęć, a nade wszystko nieumiejętność racjonalnego przeciwstawienia się wszechobecnemu złu i wykorzystania dobra płynącego/zawartego we wspomnianych treściach.

Doświadczając coraz powszechniej konsekwencji globalizmu, można odnieść wrażenie, że obecnie nikt nie ma pomysłu, jak globalną wspólną przestrzeń poddać odpowiedzialnej kontroli. Jak zauważył Zygmunt Bauman, straciliśmy kontrolę nad światem, który sami stworzyliśmy (Żakowski, 2010, s. 32). Refleksja ta rodzi wyzwanie, zwłaszcza że „w stanie obecnego nieładu światowego, w którym wszystko się może zdarzyć, a nic nie można zrobić, daleko nie pociągniemy. Zwłaszcza że rzeczywistość nie stoi przecież w miejscu. Jak czegoś nie wymyślimy, wszyscy pójdziemy na dno. Chroniczny nieład, który wszystkich ciągle zaskakuje, na dłuższą metę jest nie do wytrzymania" (Żakowski, 2010, s. 32). Wobec powyższego pozostaje kreowanie świadomości zorientowanej na nową/różnorodną rzeczywistość, co jednak, jak trafnie określił Z. Bauman, nie jest proste, zważywszy, że porządek świata rozsypał się z roku na rok, a mentalność i myślenie ludzi specjalnie się nie zmieniły (Żakowski, 2010, s. 32).

Zmiana sposobu myślenia społeczeństw wydaje się współcześnie imperatywem społecznym/priorytetem wobec płynnej nowoczesności, która sukcesywnie napełnia się różnorodnością, z którą, jak ilustruje codzienność, nie potrafimy/nie chcemy sobie poradzić. „Hannah Arendt zachwycała się pismami Lessinga nie tylko dlatego, że pierwszy napisał, iż różnorodność ludzka pozostanie na wieki, ale i dlatego że podobnie jak Arendt, serdecznie się z tej perspektywy cieszył. Bo w różnorodności widział źródło popędu twórczego, rozwoju... To jest nasz największy kapitał w epoce globalizacji" (Żakowski, 2010, s. 33). Trafnie już kilka lat temu zauważył Stanisław Kawula: „wyzwania są rodzajem psychicznego i społecznego nacisku, ażeby pewne zjawiska czy kwestie dostrzec, a następnie szukać programów ich rozwiązywania. Na tej też podstawie powstają planowe zadania, które podejmują - w ujęciu pedagogiki społecznej - poszczególne komponenty życiowej egzystencji człowieka" (Kawula, 2010, s. 121).

Kto i w jak sposób może zmieniać sposób myślenia i zachowania społeczne wobec współczesnych wyzwań? Przy poszukiwaniu odpowiedzi nasuwa się wiele podmiotów/środowisk/instytucji, które winny aktywnie uczestniczyć w procesie kształtowania przedmiotowych zmian, czyli edukacji. To zasadniczo podstawowe środowiska wychowawcze: rodzina, szkoła, grupa ró- 
wieśnicza, środowisko lokalne wraz z obecnymi tam instytucjami oraz środki masowego przekazu. Każdy z przywołanych podmiotów posiada określone role i funkcje w procesie socjalizacji, wychowania i edukacji. I mimo że w naturalny sposób - i słusznie - oddajemy pierwszeństwo i rangę w owych działaniach rodzinie, to niezwykle istotne pozostaje przekonanie o konieczności kooperacji wszystkich wspomnianych podmiotów - w tym szkoły/nauczyciela - zorientowanych na osiągnięcie zamierzonego celu, jakim jest zmiana/korekta sposobu myślenia o współczesnym zróżnicowanym kulturowo świecie.

Poznawanie, oswajanie i przygotowanie młodego pokolenia do aktywnej i satysfakcjonującej obecności w zróżnicowanym kulturowo i społecznie świecie, w którym nieład zbyt często wyznacza i modeluje codzienne życie, to nakaz cywilizacyjny, aksjologiczny i zdroworozsądkowy. Nakaz, który przybierając formę wieloaspektowej edukacji, winien uwzględnić w dominującym stopniu potencjał i wartość sztuki.

\section{Nauczyciel wobec wyzwań współczesności - redefinicja zadań i funkcji czy świadomość potrzeb?}

Nie uchybiając żadnemu ze wspomnianych podmiotów odpowiedzialnych za kształtowanie pożądanych zmian w sposobie myślenia poszczególnych grup społecznych, zwłaszcza młodego pokolenia, uwagę pragnę skierować na szkołę, która „jest swoistą agendą socjalizacji wtórnej, gdzie dziecko uczy się żyć w zbiorowości innej niż rodzina. Tu dowiaduje się, że jest członkiem narodu i obywatelem państwa, uczy się związanych z tym ról” (Wilk, 2006, s. 67).

Zamysł ukierunkowania rozważań w przedmiotowym zakresie wokół szkoły/nauczyciela nie jest przypadkowy i nie wynika li tylko z faktu, że to jedno z podstawowych środowisk wychowawczych, ale też z obserwacji szkolnej rzeczywistości, która ukazuje ignorancję wobec potrzeby systematycznej edukacji w zakresie odmienności, ale też brak wiedzy i chęci zmiany tej postawy. Brak reakcji ze strony nauczycieli kształtuje pole przyzwolenia wszelkim przejawom dyskryminacji i przemocy, którą dość powszechnie obserwuje się w szkole i poza nią, w relacjach społecznych. Trafnie zauważa Joanna Podgórska: „Polski system oświaty nie radzi sobie z dyskryminacją. Nie potrafi na nią reagować i nawet nie próbuje zapobiegać. A atmosfera, jaka panuje wokół tematu imigrantów, jeszcze tę sytuację pogarsza"(Podgórska, 2016, s. 42). Zatrważający jest fakt, że często sami nauczyciele nie tylko nie reagują na przejawy dyskryminacji/przemocy, ale sami w procesie edukacyjnym posługują się przykładami/ metodami, które uchybiają godności człowieka reprezentującego odmienną 
kulturę, rasę czy wyznanie (Podgórska, 2016, s. 42-43). Konsekwencją takich postaw jest powielanie wzorów przez młodzież, która upowszechnia je w swoim środowisku.

W ostatnim raporcie Towarzystwa Edukacji Antydyskryminacyjnej „Ostatni dzwonek”, autorki przeanalizowały reakcje władz oświatowych na incydenty dyskryminacyjne w szkołach. Tylko w jednym z ujawnionych przypadków reakcja była prawidłowa. „Nauczyciel, który widział pobicie, natychmiast interweniował, dyrekcja ujawniła całą sprawę, powiadomiła rodziców, a dla uczniów zorganizowała zajęcia na temat szacunku dla inności i tolerancji”(Podgórska, 2016, s. 42). Jak zauważają autorki, takie postępowanie to wyjątek. Generalnie w szkołach nie ma żadnych reguł czy standardów postępowania w takich sytuacjach. W tym kontekście nasuwa się kilka pytań, czy brak opracowanych standardów jest rzeczywiście przeszkodą w regulowaniu postępowań w określonych sytuacjach, kto pracuje w szkołach i jaki poziom moralności i odpowiedzialności reprezentują nauczyciele, że potrzebują specjalnych dyrektyw? Być może to też brak odwagi - i to byłoby pewnym usprawiedliwieniem - uwzględniając postawy i działania organów nadrzędnych przyzwalających na dyskredytowanie samych nauczycieli.

„Szkoła nie funkcjonuje w oderwaniu od społecznego kontekstu, a wzrost nastrojów ksenofobicznych (...) może sprawiać, że problem dyskryminacji będzie narastał. [...] Próby radzenia sobie z problemem to indywidualne inicjatywy odważnych i otwartych nauczycieli czy dyrekcji. Ale brakuje im systemowego wsparcia. Kuratoria ograniczają się do doraźnych kontroli, gdy coś się wydarzy. [...] Resort problem dyskryminacji ignoruje. Śladowe przejawy aktywności Ministerstwa Edukacji w tej mierze zamarły po zmianie władzy"(Podgórska, 2016, s. 43). W perspektywie wieloletnich doświadczeń wprowadzania zmian i regulacji w polskiej szkole nie należy się spodziewać rychłych działań w przedmiotowej kwestii. Pozostaje nadzieja, że pewne działania podejmą sami nauczyciele, odpowiedzialni i świadomi zagrożenia, jakie rysuje się w sytuacji zaniechania i bierności wobec wieloaspektowej dyskryminacji.

Nauczyciel w środowisku szkolnym jest postacią kluczową, zważywszy na zadania i funkcje, jakie szkoła ma do spełnienia. Niestety instytucja/postać nauczyciela w perspektywie ostatnich kilku dekad uległa - zapewne nie tylko w moim odczuciu - swoistej deprecjacji. Przyczyn tego stanu jest wiele, jednak to, co najistotniejsze, to dość powszechny brak świadomości społecznej - reprezentowanej przez polityków, organy decyzyjne, rodziców oraz szeroko rozumiane społeczeństwo - utrwalanie i powielanie negatywnego wizerunku 
nauczyciela poprzez jego dyskryminację (finansową, moralną i kulturową), redukcję jego praw i realnych możliwości ich dochodzenia, w istotny sposób modeluje zachowania społeczne, kształtuje mechanizmy zaniechania/marginalizacji odpowiedzialności i kontroli społecznej, zwłaszcza wobec młodego pokolenia, co w konsekwencji skutkuje negatywnymi postawami młodych ludzi w pierwszej kolejności wobec własnych rodziców - co jest w pełni logiczną konsekwencją. Prawdziwy problem pojawia się wtedy, kiedy owe negatywne zachowania - co warto podkreślić, w podstawowym stopniu warunkowane postawami rodzicielskimi - przenoszą się na szerszy zakres, społeczny/lokalnych środowisk. Rzeczywistość ujawnia szereg przykładów braku współdziałania rodziców i nauczycieli na rzecz dobra ucznia. Nader często mamy do czynienia z wrogą i roszczeniową postawą rodziców nastawionych li tylko na krytykę - często bezzasadną - nauczyciela, bez najmniejszego krytycznego spojrzenia na swoje poczynania vs. zaniechania wychowawcze, pozbawione kontroli i odpowiedzialności.

Czynię owe uwagi nie bez zasady, bowiem utrwalanie wspomnianej sytuacji, co niestety dzieje się przy pełnym przyzwoleniu społecznym oraz politycznym, tj. władz odpowiedzialnych za kształt edukacji i wychowania w naszym kraju, permanentnie będzie generowało nieład społeczny, a refleksja Zygmunta Baumana o utracie kontroli nad światem - nawet w tym lokalnym wymiarze - będzie nadal aktualna.

Pomimo tak często negatywnie postrzeganego wizerunku nauczyciela nadal pozostaje on jednym z głównych kreatorów zmian. Realizowane aktywności edukacyjno-wychowawcze w szerokiej perspektywie społeczno-kulturowej zorientowane są na przygotowanie jednostki, umiejętnie wykorzystującej posiadany potencjał dla dobra własnego i społecznego. Zamysł szerszej perspektywy edukacyjnej prezentowanej przez - w co wierzę - znakomitą większość nauczycieli podyktowany jest nie tylko obowiązującą podstawą programową, ale świadomością i odpowiedzialnością wobec wydarzeń i wyzwań współczesnej globalnej przestrzeni.

Odpowiedzialnej realizacji współczesnych zdań edukacyjno-wychowawczych służy w istotnym stopniu system edukacji kandydatów na nauczycieli, jak i system edukacji permanentnej dla aktywnych nauczycieli, oparty o sprawdzone koncepcje (Pituła, 1999).

Realia współczesności niezmiennie weryfikują nie tyle role nauczyciela, które tak naprawdę od lat wydają się niezmienne, co raczej ich terminologię, zakres i sposoby realizacji. Obecny wizerunek nauczyciela budują role, które pełni on wobec wychowanków oraz lokalnego środowiska, to nade wszystko 
rola edukatora, wychowawcy i etyka. Ostatnie dekady włączyły również role kreatora i pracownika socjalnego, co bezpośrednio związane jest z potrzebami rynku, zaistnienia w przestrzeni zawodowej oraz wsparcia socjalnego wobec sytuacji kryzysowych w coraz większym stopniu doświadczanych przez rodziny, a w konsekwencji przez uczniów.

Akces Polski do struktur Unii Europejskiej wyznaczył jeszcze inny kierunek/obszar zadań, jakie generuje aktualna rzeczywistość - „europejski”. jakkolwiek nie jest to zadanie w pełni nowe, to jednak zmiany w sferze ekonomicznej, gospodarki rynkowej, systemu politycznego, otwartości w sferze społecznej i kulturowej spowodowały potrzebę dostosowania szeroko rozumianych kompetencji nauczyciela do zaistniałych potrzeb. Edukacja europejska to nade wszystko kształtowanie otwartości na różnorodność wielokulturową, to kształtowanie umiejętności obserwacji, słuchania i korzystania $\mathrm{z}$ dorobku/dziedzictwa innych/odmiennych kultur. Jak, u schyłku XX wieku, zauważyła Henryka Kwiatkowska (1996, s. 264-273), nowa rola nauczyciela Europejczyka winna wyrażać się w przekraczaniu własnej kultury, sposobu myślenia, posługiwania się własnym językiem oraz zmianie przyzwyczajeń i świadomości. Nauczyciel winien poznawać obce kultury, języki, by jak najpełniej przekazywać wiedzę i kształtować świadomość ucznia oraz chęć i umiejętność czerpania z coraz bardziej dostępnej różnorodności.

Nauczyciel nie może pozostawać tylko źródłem wiedzy dla młodych ludzi, ma być inspiratorem czy mentorem w praktyce podejmowanych działań. „(Po)nowoczesna pedagogika - jak postulują Melosik i Szkudlarek - nie powinna angażować się w przekazywanie młodzieży gotowych do »spożycia« wersji świata, w której młodzież mogłaby łagodnie się umiejscowić. Takich światów jest bowiem niezliczona ilość, a każdy z nich oferuje »coś za coś« (...). Niech młodzież wykreuje swoją własną, osobistą wersję świata - tak brzmi nowy paradygmat, którego presji nie może nie odczuwać współczesny nauczyciel" (Bernasiewicz, 2006, s.19). To nie jest łatwe zadanie, ale wobec kontrolowanych i niekontrolowanych zmian to potrzeba, którą muszą uświadomić sobie w równym stopniu uczniowie, rodzice i nauczyciele.

Wyjątkową rolę nauczyciela - wychowawcy dostrzegała Irena Wojnar, pisząc: „Podstawowa troska edukacyjna w świecie współczesnym wyraża się w poszukiwaniu sposobów doskonalenia jakości i świata, i człowieka w ich wzajemnej interakcji. Edukacja wiąże się w sposób zasadniczy z szansą człowieka, jego rozwoju, twórczego działania, jego samorealizacji - a tego może dokonać tylko nauczyciel twórczy, kreatywny, świadomy swego zawodu i zadań" (1996, s. 68). Ten obraz współczesnego nauczyciela winna dopełniać też 
odpowiedzialność za siebie (prezentowane wartości, postawy) oraz za ucznia. A także odwaga wyrażana postawą wobec obserwowanego zła - przemocy, dyskryminacji. „Pełnione przez nauczyciela funkcje nakładają na niego obowiązek ożywienia nie tylko środowiska szkolnego, lecz także lokalnego, rozbudzając w uczniach potrzebę permanentnego rozwoju" (Wilk, 2006, s. 68). Co znamienne, nauczyciel, funkcjonując w zróżnicowanych - społecznie i kulturowo - środowiskach, nie tylko realizuje założone funkcje w przestrzeni instytucji społecznej, jaką jest szkoła, ale w bezpośredni i pośredni sposób modeluje przestrzeń lokalnego środowiska. „Funkcje społeczne nauczyciela i skorelowane z nimi role nacechowane są znacznym zakresem ambiwalencji i niejednokrotnie sprzeczności. Zajmując pozycję przypisaną inteligencji, jednocześnie umiejscowiony jest on w przestrzeni licznych wpływów wynikających z uwarunkowań społeczeństwa zglobalizowanego, jak również społeczeństwa asymilującego wzorce ostentacyjnej konsumpcji i wyrażającego na nią zgodę. Reprezentuje typ tożsamości sfragmentaryzowanej tak jak jego uczniowie, funkcjonuje na pograniczu identyfikacji z kulturą wysoką, elitarną, jak również popularną. [...] O ile odczarowana, w ujęciu Maxa Webera, nowoczesność uznawała i podkreślała metanarracyjny autorytet nauczyciela, to refleksyjna późna nowoczesność zakwestionowała kategorię racjonalności społecznej, dotychczasowych zasad organizacji i charakteru cech przypisywanych rolom, wskazując na ich relatywny i historyczny, a więc dyskusyjny charakter" (Bielska, 2006, s. 64).

Zapewne można z tą refleksją polemizować, ale nie zmienia to faktu, że realizacja zadań wpisanych w rolę nauczyciela wymaga odpowiednich kompetencji: merytorycznych, dydaktycznych i wychowawczych. Holistyczne postrzeganie i wyrażanie wspomnianych kompetencji zaświadcza zarówno o odpowiedzialności i wrażliwości społecznej oraz świadomości potrzeb i wyzwań, jakie kreuje współczesność, w tym otwartość na zmiany oraz chęć porzadkowania obecnego nieładu, m.in. rewitalizując historyczne metody kształcenia i wychowania oparte w znacznym stopniu na sztuce.

Skłaniając się do odpowiedzi na pytanie postawione w śródtytule, uwzględniając zadania i funkcje, które nauczyciel pełnił w przeszłości oraz te, które obecnie pełni, jestem przekonana, że nie istnieje potrzeba redefinicji owych ról czy funkcji, ponieważ zmianie nie ulega ich istota, a tylko okoliczności, wielość i różnorodność zadań, zdarzeń, zjawisk, wobec których trzeba reagować. Nawet formy - w pewnym zakresie - powinny pozostać takie jak w przeszłości (szkoły jezuickie czy pijarskie). Byłyby w istotnym stopniu gwarantem sukcesu. 


\section{Zastosowanie sztuki w szkolnym procesie oswajania zachodzących zmian. Kształcenie i wychowanie w procesie porządkowania świata}

Erwing Goffman uważał, że „świat jest w istocie uroczystością, w której wszyscy bierzemy udział" (Goffman, 1981, s. 65). Czy rzeczywiście wszyscy mają poczucie uczestniczenia w tej uroczystości, jaką jest świat? Jeżeli tak, to $w$ jakim zakresie, czy są beneficjentami obecnej rzeczywistości, mogącymi korzystać z wszelkich wypracowanych dóbr, czy raczej mają poczucie outsiderów, którzy równego dostępu do dóbr „zostali pozbawieni”?

Z kolei Anthony Giddens zauważał, że: „Rzeczywistość wysoko rozwiniętej nowoczesności to rzeczywistość szans i ryzyka, które są koniecznym dopełnieniem systemu zorientowanego na dominację nad przyrodą i refleksyjne tworzenie historii. Formalnie rzecz biorąc, los i przeznaczenie nie mają żadnej roli do odegrania w tym systemie, który (z zasady) funkcjonuje za sprawą, (...), ludzkiej kontroli nad przyrodą i społeczeństwem. Świat przyszłych zdarzeń jest kształtowany przez ludzi w miarę możliwości określonych przez szacunek ryzyka"(Giddens, 2002, s. 150).

W obu fragmentach daje się jednoznacznie odczytać potrzebę działania (aktywności). Owe wspomniane formy identyfikuję z określoną koncepcją, kreowaniem otaczającej jednostkę rzeczywistości, z pracą, która pozwoli na realizację idei własnego i społecznego życia. Idąc torem myślenia zaproponowanym przez Anthony Giddensa, współczesny człowiek, dysponując rozumem, prawem i dostępem do edukacji oraz chęcią, może i powinien indywidualnie i odpowiedzialnie kształtować własny życiorys. To kwestia posiadanego habitusu, stosując terminologię Pierre’a Bourdieu, który stymuluje ludzi do aktywności i działania. Podobne zalecenia stosowała Helena Radlińska. Aktywizacja oparta na świadomości przemian i potrzebie regulowania relacji społecznych wydaje się obecnie priorytetowym zadaniem edukacyjnym. Zwłaszcza w sytuacji narastającej ksenofobii i lęku wobec odmienności.

Przestrzeń obaw i lęków w coraz większym stopniu generuje kategoria Obcego/Innego, która nie musi odnosić się do odmienności natury etnicznej, narodowościowej czy rasowej. Obcym może być reprezentant tego samego narodu, który swoimi poglądami, postawami, stylem życia - znacząco lub w pewnym zakresie - odbiega od powszechnych „upodobań” społecznych. Owa inność implikująca lęk i obawy odnosi się zasadniczo do identyfikowalnych różnic etnicznych, rasowych, religijnych i kulturowych, które często 
manifestowane są już samym wyglądem zewnętrznym. Brak wiedzy, świadomości kreuje postawy wrogości i niechęci wobec wszelkiej odmienności: religijnej, kulturowej, społecznej czy etniczno-rasowej.

W „obrazie” współczesnej Europy widzimy funkcjonujące obok siebie, pracujące w tych samych firmach, realizujące własne scenariusze życiowe na tych samych obszarach, jednostki reprezentujące różne narodowości, kulturę, rasę oraz przeszłość historyczną, która w nieodległej perspektywie diametralnie różniła. Teraźniejszość, wspólnota interesów, zmiana sposobu myślenia, świadomość społeczna, wreszcie potrzeba pokojowego tworzenia rzeczywistości spowodowały w znacznej mierze całkowite przeobrażenia umożliwiające współistnienie na wielu płaszczyznach aktywności człowieka. I mimo powszechnej unifikacji wielu dziedzin nie spowodowało to jednak dysfunkcji zachowania odrębności narodowej (etnicznej) kultury, zachowania odmienności religijnej, tudzież wyrażania na różne sposoby swoich przekonań, upodobań. Funkcjonowanie w nowej/innej kulturze zdecydowanie bardziej dostarcza nowych bodźców do rozwoju oraz wyeksponowania własnej kultury niż do jej unicestwienia.

Na tym samym „obrazie” widzimy również przejawy ksenofobii, dyskryminacji, przemocy, nietolerancji, braku szacunku wobec odmienności. Czy istnieje szansa na likwidację owej dwoistości i wyeksponowanie tylko pozytywnego obrazu? Chcę wierzyć, że tak.

Ową szansą na oswojenie odmienności jest edukacja. To, co obecnie obserwujemy, już tylko w przestrzeni europejskiej, winno stać się źródłem refleksji i materiałem edukacyjnym dla konstruowania bezpiecznej przyszłości.

Istotnym elementem procesu edukacyjnego jest otwartość/zgoda na pojawienie się czegoś nowego. To chęć zaakceptowania/przyjęcia nowych Obcych/ Innych członków społeczności, współtworzących daną wspólnotę, wraz z ich poczuciem tożsamości, wartości i kultury. Rzeczywistość wymaga permanentnej edukacji, zwłaszcza w kontekście coraz powszechniejszej globalnej wielokulturowości. W aktualnej rzeczywistości pojawia się zasadnicze pytanie, które trafnie sformułował Jerzy Nikitorowicz: „Jak edukować dzieci, młodzież i dorosłych, aby trwać ze swoimi wartościami i równocześnie uczestniczyć w procesie integracji, nie znikać kulturowo w globalnym świecie?" (Nikitorowicz, 2009, s. 186). To istotne pytanie w perspektywie podejmowanych zadań edukacyjnych, sugerujące potrzebę rozumienia istoty wielokulturowości. Jak zauważają autorzy Raportu dla UNESCO, wielokulturowość wymaga ,...lepszego rozumienia innych, lepszego rozumienia świata; konieczność wzajemnego zrozumienia, pokojowej wymiany idei, czy wręcz jedności. Tego najbardziej brakuje naszemu 
światu" (Edukacja, 1998, s. 17). Niezbędna jest zatem edukacja do kształcenia rozumienia odmienności. Zrozumienie staje się z kolei kluczem do porządkowania świata. Międzynarodowa Komisja do spraw Edukacji dla XXI wieku dla UNESCO, jak zauważa Jerzy Nikitorowicz, zwraca szczególną uwagę na jeden z czterech podstawowych filarów edukacji: „uczyć się aby żyć wspólnie z innymi - poprzez wzbogacanie wiedzy o innych, ich historii, tradycji, duchowości. W ten sposób można zachęcać do realizacji wspólnych planów i pokojowego rozwiązywania nieuniknionych konfliktów. Pozostałe trzy filary miałyby dostarczać podstawowej wiedzy, jak uczyć się aby żyć wspólnie; uczyć się, aby wiedzieć, aby działać, aby być" (Nikitorowicz, 2009, s. 187).

W kontekście coraz powszechniej zaznaczającej się wielokulturowości „punktem wyjścia jest kultura, która stanowi wyzwanie dla edukacji i daje podstawę do działań edukacyjnych, a efektem jest rozwijająca się i wzbogacająca ustawicznie tożsamość człowieka i grupy, kreowana poprzez aktywność i twórcze działania" (Nikitorowicz, 2009, s. 11). Świadomość owego stwierdzenia winna charakteryzować działania współczesnego nauczyciela. Czy zasadne jest doszukiwanie się analogii nauczyciela do pracownika kultury? Wydaje się, że tak. „Pracownicy kultury - czy to nauczyciele, dziennikarze, artyści, czy urzędnicy państwowi - są postrzegani jako ludzie upowszechniający kulturę za pomocą języka, wartości postaw, obrazów, zasad i informacji. [...] C. Wright Mills dowodzi, że aparat kultury składa się ze wszystkich organizacji, w których odbywa się praca artystyczna, intelektualna lub naukowa, a zatem dotyczy złożonego szeregu instytucji, włączając w to szkoły, teatry, gazety, pracownie, laboratoria, muzea i czasopisma” (Meighan, 1993, s. 42). Co prawda: „W przeciwieństwie do aktora na scenie, nauczycielowi nie dano ekscytującego scenariusza napisanego przez wielkiego dramaturga. Nie dane jest mu czerpać korzyści z charakteryzacji i kostiumu, a dodatkową trudnością jest konieczność pojawiania się przed uczniami dzień po dniu (...)” (Meighan, 1993, s. 42). To jednak nie umniejsza jego związku z kulturą, czy nawet poszczególnymi dziedzinami sztuki, przeciwnie świadomego i odpowiedzialnego nauczyciela, który chce i potrafi korzystać z dziedzictwa kulturowego sytuuje w pozycji kreatora prawdy, piękna i dobra. E. Cassirer (1977, s. 17), autor koncepcji kultury jako symbolicznych form, postrzegał kulturę jako środek ratowania człowieka zagrożonego otaczającą go rzeczywistością. To refleksja w pełni wpisująca się w obecną rzeczywistość.

Kultura jako zjawisko/dziedzictwo historyczne i kulturowe jest siłą, wartością, potencjałem kreowania dobra. Dlatego zapewne „Wilhelm Diltheh wskazał, że człowieka można zrozumieć przede wszystkim poprzez histo- 
rię i kulturę, która zaspokaja jego potrzeby duchowe. [...] Kontakt człowieka z kulturą odbywa się dzięki przeżywaniu i rozumieniu wartości, a to osiąga się w procesie edukacji" (Nikitorowicz, 2009, s. 17).

Pośród wielości form/metod działania pedagogicznego nauczyciela w przestrzeni kultury jest miejsce na sztukę. Jak pokazuje historia, zaangażowanie sztuki, poszczególnych jej dziedzin, w procesie dydaktyczno-wychowawczym pozwala skutecznie osiągać zamierzone rezultaty. Diagnoza współczesnych podstaw programowych, a także autorskich programów nauczycieli na wszystkich poziomach edukacji, wskazuje na stosunkowo niewielkie wykorzystanie sztuki w edukacji. Można powiedzieć, że nauczyciele prezentują swoisty opór wobec sztuki, co przekłada się w znacznym stopniu nie tylko na brak przedmiotowej wiedzy, ale także na wspomniane negatywne postawy wobec odmienności. A szkoda, bo priorytetem współczesności winno być (co słusznie postulują artyści) dążenie do umiejętności obserwacji rzeczywistości i praktycznego działania z wykorzystaniem oferty, jaką daje nam sztuka. Problemem podstawowym w spełnieniu tego zamysłu jest nie tyle brak dostępności sztuki - muzyki, plastyki, sztuki teatralnej - w naszym codziennym życiu, lecz chęć uczestniczenia w jej ofertach, a dalej brak umiejętności odczytania komunikatu, który zawiera.

Sztuka nie może być tajemnicą, obszarem dostępnym tylko nielicznym odbiorcom, jako że jest „zjawiskiem społecznym, mającym swoje społeczne uwarunkowania, społeczną recepcję i społeczne funkcje. Jako zjawisko społeczne należy do sfery komunikowania się, mówiąc inaczej - jest formą społecznego, bo ludzkiego dialogu. Interesuje zatem przedstawicieli wielu dyscyplin naukowych: estetyków, filozofów, psychologów, pedagogów i socjologów" (Goban-Klas, 1971, s. 7). Wydaje się, że pedagogów nadal w zbyt małym zakresie.

Tymczasem uwzględniając zaniechania rodziny w kształtowaniu wychowania przez kulturę/sztukę, to przed nauczycielem staje zadanie wdrożenia sztuki w proces edukacyjny i zainteresowania ucznia rodzimym dziedzictwem kulturowym oraz kulturą/sztuką innych narodów. Sztuka, modelując wartości i więzi społeczne w perspektywie sytuacji konfliktowych, jawi się jako narzędzie użyteczne zarówno w sferze kompensacji powstałych niesprawności, jak i ich profilaktyki. „Potwierdzają to już badania z przełomu XIX i XX wieku - postrzegające sztukę jako dziedzinę utrzymującą związki ze społeczeństwem, nie jak dawniej tylko w ujęciu biernym, ale jako dziedzinę, którą kształtuje społeczeństwo i która przez to społeczeństwo jest kształtowana" (Wilk, 2010, s. 63).

Potwierdzenia istotności i znaczenia sztuki, jej poszczególnych dziedzin, w praktyce społecznej dostarcza nie tylko przedmiotowa literatura, ale i przy- 
kłady konkretnych rozwiązań w lokalnych środowiskach. „Sztuka może stać się istotna i zazwyczaj taką się staje najczęściej w sytuacji kryzysowej, kiedy zagrożony jest istniejący ład lub jego postrzeganie w świadomości jednostek" (Krajewski, 1995, s. 63).

Sztuka jest relacją/ilustracją teraźniejszości, ale też prognozą przyszłości. Artyści, obserwując rzeczywistość, wybierają konkretne tematy, budując na ich kanwie określone dzieło, które - jak w teorii Rzeźby społecznej Josepha Beuysa - staje się przekazem/komunikatem kierowanym do odbiorcy. Zamysłem artystów jest zainicjowanie dialogu wokół przedstawionego tematu, refleksji, a może rewizji postaw.

Oferta poszczególnych dziedzin sztuki jest bardzo bogata, trzeba tylko chcieć z niej skorzystać. I to jest zadanie dla nauczyciela.

W kontekście tytułowego zagadnienia - nieładu światowego - i potrzeby jego oswajania z wykorzystaniem sztuki chciałabym zaproponować spojrzenie na trzy wybrane propozycje, z zakresu filmu i teatru, które odnoszą się do współczesnych niepokojów, zagrożeń dotyczących zwłaszcza młodego pokolenia. Leszek Kołakowski w swoich publikacjach wskazuje na istnienie zła w każdym z nas, na jego wszechobecność. „Każe nam je widzieć, nie spuszczać z niego oka. I wiedzieć, że rezygnując z działania, godzimy się, by ono działało. Zawsze dokonywać musimy etycznych wyborów. One są trudne, zwłaszcza w czasach trudnych. W żadnych gotowych kodeksach etycznych nie znajdziemy gotowych odpowiedzi. Odpowiedzialność za wybór zawsze spoczywa na każdym z nas" (Poprzeczko, 2016, s. 59).

Filmową ilustracją refleksji znakomitego filozofa jest film „Pan Lazhar” Philippe Faladeau, z 2013 roku. Tak jak mówili krytycy, ta mądra przypowieść o szkole jest filmem powstałym na podstawie sztuki teatralnej, ukazującej potrzebę budowania więzi, terapii po doznanych doświadczeniach, wreszcie potrzeby prowadzenia bezpośredniej rozmowy. Miejscem akcji filmu jest szkoła, ukazana tu jako metafora skonfliktowanego społeczeństwa. Kluczową kwestią przedstawioną w filmie jest: „....relacja nauczyciela z wychowankami. Rzecz nie dotyczy jednak trudności dogadywania się ludzi pochodzących $\mathrm{z}$ odmiennych środowisk i kultur, tylko empatii i otwierania się na cierpienie, pomimo dzielących różnic. Traumę przeżywają w filmie obie strony: dzieci z montrealskiej podstawówki, które muszą zmierzyć się z samobójczą śmiercią ich ulubionej nauczycielki (...). Oraz ich nowy wychowawca, algierski imigrant, starający się odzyskać psychiczną równowagę po stracie całej swojej rodziny. Niekonwencjonalne metody pracy obcego, zaufanie i czułość, jaką okazuje klasie, łamią bariery, ale też budzą kontrowersje. [...] Karci je, dotyka, 
rozmawia otwarcie o przemocy i śmierci" (Wróblewski, 2013, s. 69). Film wpisuje się nie tylko w kontekst nieładu społecznego, jak widać nie tylko osób dorosłych, ale także w aktualne - czy na pewno retoryczne - pytanie, czy szkoła ma uczyć, czy także wychowywać i jakimi metodami to czynić? Czy nadal to pytanie, nie tylko w kontekście przywołanego filmu, jest zasadne?

Pod koniec XX wieku francuski socjolog Alain Touraine w książce pod tytułem „Czy potrafimy jeszcze żyć razem?” (1997), podejmując próbę odpowiedzi na to pytanie, , analizował kondycję społeczeństwa, rozpadającego się w wyniku procesów indywidualizacji. Co z tego, że człowiek zaopatrzony jest w naturalne predyspozycje do kooperacji, skoro najwyraźniej potrzebne do tego geny przestały być aktywne" (Pruski, 2012, s. 63). Czy rzeczywiście aktywność genów współdziałania, współpracy wygasła i czy możemy je jeszcze poddać rewitalizacji?

Próbą odpowiedzi jest film dokumentalny „Szkoła Babel” Julie Bertuccelli. Obraz ukazuje zjawisko multikulti w szkole. „24 uczniów pochodzących z 24 państw w jednej klasie. Przyjechali do Francji z całego świata, z nadziejami na lepsze życie. Decydowały względy ekonomiczne, ale niektórzy musieli opuścić kraj dzieciństwa z powodów politycznych (chłopak żydowskiego pochodzenia źle czuje się w Serbii) (...). Różne języki macierzyste, różne kolory skóry, różne religie - prawdziwa »Szkoła Babel«. Na razie przez rok będą uczyć się głównie języka francuskiego, ale także bycia ze sobą w grupie, pokonywać barierę obcości. [...] Na pewno jedną z postaci, o której będziemy długo pamiętać po wyjściu z kina, jest czarnoskóra Rama. Ma pozostać na drugi rok w tej klasie przygotowawczej. Dziewczyna nie może pogodzić się z wyrokiem rady pedagogicznej, zarzuca nauczycielce, że nie dostała promocji tylko dlatego, że jest czarnoskóra. To bardzo dramatyczna rozmowa, pokazująca, że w klasie przypominającej wieżę Babel nie wszystkie historie kończą się happy Endem. [...]" (Pietrasik, 2015, s. 96). Autorom udało się przedstawić młodych ludzi rozmawiających o swoich religiach, kulturze i upodobaniach. Mimo sytuacji problemowych, które ukazuje film, odnajdujemy tu przykład próby porozumienia pomiędzy młodymi ludźmi, porozumienia dzięki bezpośredniej rozmowie, która staje się idealnym narzędziem poznania, a może zrozumienia.

„Warunkiem rozmowy, dialogu mającego doprowadzić do wzajemnego zrozumienia i porozumienia, jest empatia i wynikająca z niej zdolność do wysłuchania i zrozumienia stanowiska interlokutora. Wiara, że nowe techniki komunikacyjne w naturalny niejako sposób rozwijać będą taką właśnie kulturę rozmowy, okazała się na razie płonna. Dotychczasowe doświadcze- 
nie uczy, że Internet sprzyja raczej polaryzacji stanowisk i ułatwia integrację struktur neotrybalnych. [...] Natura wyposażyła człowieka w zdolność do kooperacji i do komunikowania się. Te kompetencje nie gwarantują jednak wcale przetrwania. Zależy ono od kultury - umiejętności rozmowy - sztuki, której trzeba nieustannie się uczyć" (Pruski, 2012, s. 63).

Richard Sennett „dostrzega złowrogi proces i niezrażony tym przekonuje, że jeśli chcemy uniknąć katastrofy, musimy zacząć skromnie, od odzyskania kluczowej dla otwartej współpracy umiejętności - rozmowy. W odpowiedzi można wykrzyknąć: wszak jeszcze nigdy komunikacja międzyludzka nie była tak silna! Uzbrojeni w komórki, Internet ze Skype'em, Facebookiem, Twitterem, blogami i forami dyskusyjnymi ludzie gadają jak najęci. Owszem, debatują przekonując do swoich racji, lecz nie rozmawiają" (Pruski, 2012, s. 63).

Brak edukacji i pielęgnowania kultury rozmowy, zaniku/labilności tożsamości, brak zakorzenienia, identyfikacji czy poczucia wspólnotowości prezentuje spektakl zatytułowany „Airport Kids”. To wymowny przykład prognozy przyszłości. Bohaterami projektu są dzieci/ uczniowie międzynarodowych szkół w Lozannie, „...dzieci współczesnych nomadów - wysokiej klasy specjalistów, (...), podążające za rodzicami z kraju do kraju. Filmowane w kontenerach stojących na lotniskowym cargo, wyposażone we wszystkie możliwe urządzenia do komunikowania, wygadane - opowiadają o swoim życiu i dzielą się swoimi marzeniami..." (Kyzioł, 2008, s. 54). W kontekście zaprezentowanych treści pojawia się szereg pytań: Czy przyszły świat, jego przyszłość, nie będzie jedynie produktem globalizacji, który zamieszkiwać będą osoby bez tożsamości, którym zupełnie obca będzie idea ojczyzny? Czy - jak zauważył jeden z twórców - mamy świadomość, że podejmowane decyzje, postawy, relacje, które tworzymy, powodują, że sami przygotowujemy sobie piekło na ziemi? Podobnych pytań jest wiele.

Przedstawione przykłady z zakresu filmu, teatru, ilustrujące rzeczywistość nie są prostą receptą na oswajanie zmian, są raczej materiałem poznawczym i edukacyjnym, motywacją do stawiania pytań, dzielenia się refleksjami, kształtowania konstruktywnego myślenia. Może podpowiedzią dla wychowawczych działań nauczycieli i rodziców.

\section{Refleksja końcowa}

Alain Tourain w swojej książce „Po kryzysie” (2013) zauważa, że „ekonomia podporządkowała sobie wszystkie inne sfery życia: politykę, kulturę, a na- 
wet religię. [...] Ostatnim bastionem umożliwiającym budowanie tożsamości w rozsypującym się na naszych oczach świecie jest kultura" (Bendyk, 2013, s. 74). Postrzeganie kultury jako wartości, siły czy narzędzia umożliwiającego porządkowanie współczesnego świata pojawia się coraz częściej w refleksjach wybitnych reprezentantów nauki i kultury wszystkich kontynentów. Podobny kierunek odnajdujemy chociażby w wypowiedziach Zygmunta Baumana w 2011 roku w czasie Europejskiego Kongresu Kultury, który mówił o kulturze jako kotwicy Europy i podstawowym narzędziu regulowania wzajemnych relacji w międzykulturowej przestrzeni.

Trudną rzeczywistość można oswoić - by zrobić to skutecznie, warto zaangażować w działaniach edukacyjnych kulturę i sztukę, co potwierdzają zarówno twórcy, jak też naukowcy. I chociaż „analizy Touraine’a nie napawają optymizmem, wskazują jednak, gdzie szukać informacji o teraźniejszości i możliwej przyszłości: w kulturze. Kultura jest najlepszym nośnikiem marzenia o lepszej przyszłości (...)” (Bendyk, 2013, s. 75). Lepiej w to uwierzyć i zastosować.

\section{Bibliografia}

Bendyk, E. 2013. Między mitem a rozumem. Polityka. 37, ss. 74-76.

Bernasiewicz, M. 2006. Pedagogika milczenia czy zaangażowania - o dylematach współczesnego nauczyciela. W: Pituła, B. red. Nauczyciel wobec problemów współczesności. Katowice: Wydawnictwo Śląskiej Wyższej Szkoły Zarządzania im. gen. Jerzego Ziętka w Katowicach, ss. 19-27.

Bielska, E. 2006. Postkonteksty roli społecznej nauczyciela. Wybrane aspekty dyskursu. W: Pituła B. red. Nauczyciel wobec problemów wspótczesności. Katowice: Wydawnictwo Śląskiej Wyższej Szkoły Zarządzania im. gen. Jerzego Ziętka w Katowicach, ss. 59-66.

Cassirer, E. 1977. Esej o człowieku. Wstęp do filozofii kultury. Warszawa: "Czytelnik".

Edukacja, jest w niej ukryty skarb. 1998. Jacques'a Delorsa Raport dla UNESCO. Tłum. W. Rabczuk. Warszawa: Stowarzyszenie Oświatowców Polskich.

Giddens, A. 2002. Nowoczesność i tożsamość. „Ja” i społeczeństwo w epoce późnej nowoczesności. Warszawa: PWN.

Goban-Klas, T. 1971. Z zagadnień socjologii sztuki. Kraków: PAN. 
Goffman, E. 1981. Człowiek $w$ tetrze życia codziennego. Warszawa: PWN.

Kawula, S. 2010. Pedagogika społeczna w perspektywie zmiany społecznej w Polsce współczesnej. W: Syrek E. red. Czas społeczny akademickiego uczestnictwa w rozwoju i doskonaleniu civil society. Ksiega jubileuszowa dedykowana Profesorowi Andrzejowi Radziewiczowi-Winnickiemu w 65. rocznicę urodzin. Katowice: UŚ, ss. 118-133.

Krajewski, M. 1995. Sztuka jako praktyka społeczna. Miejsce instytucji świata artystycznego w społecznej rzeczywistości. Kultura i Społeczeństwo. 1, ss. $49-63$.

Kyzioł, A. 2008. Wędrówka przez piekło. Polityka. 31, ss. 52-54.

Kwiatkowska, H. 1996. Europejskość edukacji nauczycielskiej. Geneza - wyznaczniki - konkretyzacje. W: Wojnar, I. i Kubin, J. red. Edukacja wobec wyzwań XXI wieku. Warszawa: Wydawnictwo Komitet Prognoz „Polska w XXI wieku" przy Prezydium PAN, ss. 256-274.

Meighan, R. 1993. Socjologia edukacji. Toruń: UMK.

Nikitorowicz, J. 2009. Edukacja regionalna i międzykulturowa. Warszawa: WAiP.

Pietrasik, Z. 2015. Klasa światowa. Polityka. 23, s. 96.

Pituła, B. 1999. Postrzeganie nauczyciela $w$ wybranych koncepcjach jego kształcenia. Katowice: Wydawnictwo Uniwersytetu Śląskiego.

Podgórska, J. 2016. Po dzwonku. Polityka. 17, ss. 42-43.

Poprzeczko, J. 2016. Zło wszechobecne. Polityka. 45, s. 59.

Pruski, Z. 2012. Gadać i działać. Polityka. 27, ss. 62-63.

Wilk, T. 2006. Zadania nauczyciela wobec dziecka, którego rodzina jest „nieobecna”. Refleksje na przykładzie filmu „Wrony”. W: Pituła, B. red. Nauczyciel wobec problemów wspótczesności. Katowice: Wydawnictwo Śląskiej Wyższej Szkoły Zarządzania im. gen. Jerzego Ziętka w Katowicach, ss. $66-80$.

Wilk, T. 2010. Rewitalizacja społeczna poprzez wspótczesna sztukę teatralna w ocenie reprezentantów (twórców i odbiorców) sztuki dramatycznej Legnicy, Nowej Huty $i$ Wałbrzycha. Katowice: UŚ.

Wojnar, I. 1996. Aktualne problemy edukacji i kultury w Polsce $i$ na świecie.

Warszawa: Wydawnictwo Komitet Prognoz „Polska w XXI wieku” przy Prezydium PAN.

Wróblewski, J. 2013. Grupowa terapia. Polityka. 5, s. 69.

Żakowski, J. 2010. Nowy nieład światowy. Polityka. 51, ss. 30-34. 


\section{A teacher in the face of worldwide disorder - on the need for (redefining) the consciousness of teachers' tasks in controlled and uncontrolled changes and the possibilities of using art in the process of adapting to them}

Abstract: The presented text is an attempt to draw attention to the necessity to domesticate the changes in the global space. The threats and consequences of current multifaceted changes imply the need of integrated educational actions. In this study, the attention is paid to the activity of school/teachers in the situation of world disorder. What remains an important issue is teachers' awareness and their educational and didactic activity oriented towards shaping young people's consciousness of permanent changes and the phenomenon of multiculturalism. Due to the experience of past ages, an important tool for controlling positive coexistence, social relations and functioning in a group is culture and art, which do not only reflect the reality, but also constitute an important social message, educational material, and most of all the bond connecting communities, especially multicultural ones.

Taking into consideration the value of culture/art - not only its artistry, aesthetics but also its utilitarianism, it becomes an intentional plan to incorporate culture/art into educational activities.

Keywords: changes, disorder, threats, culture, art, education, teacher, domestication, need, awareness 